\title{
Cultural Materialistic Reading of Eugene O'Neill's the Iceman Cometh
}

\author{
Mojgan Gaeini
}

Islamic Azad University, Qom Branch, Qom, Iran

Email: mogaeini@yahoo.com

\section{Fatemeh Sadat Basirizadeh}

Islamic Azad University, Qom Branch, Qom, Iran Email: nbasiri2002@yahoo.com

\section{Doi:10.5901/ajis.2013.v2n9p74}

\begin{abstract}
This paper examines one selected play of Eugene O'Neill (1888-1953) in Cultural Materialism. His selected play, The Iceman Cometh, is interwoven with the political and socio-economical conditions of the American capitalistic society. O'Neill was highly under the influence and inspiration of his contemporary events and the traces of those events are reflected in his works. He prefers to deal with the authentic American types and backgrounds in his social dramas. The main characters of his plays under the tyranny of dominant power turn into dissidents and resist against the authority or control of the dominant system. They struggle to subvert the dominant order, and since they would be a threat for absolute power they are consequently condemned to harsh punishment. O'Neill represents the conflict between the marginalized group and the central one. His sympathetic tone indicates his intention in supporting the dissidence in social and political activities. The Iceman Cometh is the depiction of the World War's impact on American community. All of the desperate typical characters of this play belong to the dissident group that resist against the dominant order in various manners. O'Neill held out little hope for man in The Iceman Cometh during the Second World War. O'Neill confessed that the United States instead of being the most successful country in the world is the greatest failure because of the foreign policy of the United States during the Wars. The Iceman Cometh is the symbolic and artistic picture of the US policy which brings disillusionment and death for Americans.
\end{abstract}

Keywords: Cultural Materialism, Dissidence, hegemony, residual, allegiance

"Ruling culture does not define Culture, though it tries to, and it is the task of the oppositional critic to re-read culture so as to amplify and strategically position the marginalized voices of the ruled exploited, oppressed and excluded." Raymond Williams.

\section{Introduction}

Cultural Materialism as a postmodernist critical approach has root in the contextual approaches. It tries to remove the deficiencies of the traditional contextual approaches and to provide a practical and well-organized theory in literary criticism. Some critics believe that the background of Cultural Materialism refers to the Historical oriented approaches, but some others maintain that it is the result of Marxism. It is important that Cultural studies have significant role in the construction of Cultural Materialism. Contextual approaches were constructed after traditional approaches and New Criticism. Their background goes back to the nineteenth and early twentieth centuries when scholars asked to what extent literary texts were under the influence of the historical, political, economical, philosophical, religious and psychological contexts of their productions. One example of the contextual approaches was Marxist criticism which regards the production of literary texts as "the interface of material and socio-economical circumstances" (Selden 88). Class and economic structures were the particular focus of Marxist critics.

Marxism views literature in terms of its relationship to society. Marxists critics study literature to examine how a literary work reinforces or undermines the current social structure. After the Second World War contextual approaches, especially Marxism, are considered as the outdated approaches. They have had a major comeback over the last two decades in approaches like New Historicism, Cultural Materialism and Cultural Studies. Thus, Cultural Materialism is somehow the revision of Marxism. Some critics demonstrate that Cultural Materialism in studying of historical contexts of the literary works has objective method and belongs to Historicism. The delicate neglected point in this claim is the special viewpoint of Cultural Materialism towards the concept of history. Brannigan declares "Cultural Materialism 
announces that not only literature is shaped by history but also shapes it as well" (92). There is organic and inseparable relation between history and literature. The most famous concept of "the historicity of text and the textuality of history" (Brannigan 195) in Cultural Materialistic theories reinforces this idea. Cultural Studies emphasize that any cultural phenomenon is valuable for serious analysis. Investigation of literature is one means to pursue Cultural Studies, but literature is no more important or significant culturally than other practices. There is no difference between literary works and other cultural products. Cultural Studies use the theories and methods of literary criticism to probe the depth culture both through the literary study and through the study of other texts or the cultural implications of popular culture.

Eugene Gladstone O'Neill was born in an Irish-Catholic theatrical family on October, 16, 1888 at the Barrette House, a hotel at Broadway in New York City. In 1912 because of mild tuberculosis he spent six months at sanatorium where he decided to become a playwright. In the late 1910s O'Neill's dramas gained recognition in New York City. Between the years 1918 to 1924 he wrote Anna Christie (1922), The Hairy Ape (1921), The Emperor Jones (1920), Desire Under the Elms (1924) and the distinguished short sea plays: Bound East for Cardiff, In The Zone, The Long Voyage Home and The Moon of the Caribbees (between 1913 to 1917). This autobiographical play was awarded the Pulitzer Prize in 1957. The Iceman Cometh (1939) also was considered as his best play in 1957, several years after its publication.

O'Neill attempted more than anyone else to destroy the rooted conventions and stereotypes of American Theatre and to substitute an essentially different dramatic imagination. The dominant dramatic genre of the nineteenth century in both Europe and America was melodrama. The recent critics argue that melodrama was a response to a "deeply unsettled post revolutionary political and social order" (Gilman 95). Melodrama depicts a simplified moral universe in which good and evil are clearly recognizable traits of a hero and a villain who are locked in a struggle for dominance that is often violent and sensational. In melodrama the forces of good usually win and affirm the established social order and assure the audience that its moral values will triumph at the end. In a typical melodrama the plot is romantic and developed sensationally with little regard for motivation and with an excessive appeal to the emotions of the audience. The object is to keep the audience thrilled by the arousal of strong feelings of pity, horror or joy. The message of the play is conveyed through sheer sentiment and there is no room for depicting the complexity of moral dilemmas or the psychological complications of human characters. The characters of the melodramas are either very good or very bad and they are involved in a reward or punishment pattern according to their deeds. Thus, each melodrama contains the abundance of stereotypes and clichés.

The play of this kind was eventually replaced by a more serious drama represented by realism of Ibsen and later refined by innovative artistry of O'Neill and other major modern dramatists. Rejecting the simplistic moral worldview, the conventional plot, the flat characters and the sensationalized staging of melodrama, playwrights such as O'Neill worked at developing a realistic theatre that represented common place middle class, American life directly and that invited its primarily middle class audience to wrestle with moral and psychological complexity rather than to reaffirm traditional values. O'Neill extricated himself from the dominant modes of dramatic expression. Manheim states "he turned his back to the conventional formulae of melodramatic romanticism and the clichés of his contemporary theatre" (22). O'Neill very artistically represents the common people with the internal combination of good and bad as his dramatic characters and conveys his message very implicitly through some more adept dramatic techniques. Thus, his dramatic career was a series of experimental efforts to liberate American drama from the dominant conventions and to find a satisfactory vehicle for representing life. The result was a new depth of seriousness and new vitality in the drama, and the free use in stage craft and acting of experimental techniques which completely ignored the established conventions.

O'Neill in his plays represents the opposition between the groups of socio-political dissident and dominant. His main characters in these three plays are those who stand against the dominant order of the society and reject to be the social and political conformist. O'Neill argues that the dominant system of his society, i.e. Capitalism, legitimates all tyrannical processes within its realm of authority. Dominant system reacts against the militant resistance either by severe punishment or by keeping it marginal. He explores the effect of perverse social arrangement on both the oppressor and the exploited through the form, language and content of his plays. He shows the repression of entire people in modern time. In O'Neill's view the matter of dissidence could take place in various fields of human being; dissidence could be social, political, moral and psychological.

In the early twentieth century during the modern period American Drama began to mature. 1920s and 1930s was a time of great experimentation in the American theatre mostly by Eugene O'Neill. It was nourished and influenced by international movement in drama, especially expressionism. O'Neill as a pioneer dramatist who brought expressionism to American theatre changed the traditional conventions in the performance of the plays. He worked upon the social drama and direct treatment of contemporary political, social and economical conflicts. O'Neill combined vigor with imagination, toughness with sensitivity and realistic detail with expressionistic devices. He was interested in the authentic American 
types and backgrounds. Hence, he preferred to state his own city- New York- as the place of his plays because he completely knew New York inhabitants and was familiar with their life and attitudes.

O'Neill in his dramatic works tries to depict the complex mental disturbance of modern man. He, contrary to the traditional dramatists who want to represent the tragic destiny of those who are not in harmony with God or with universe, attempts to convey the harsh situation of those who are not in harmony with other human beings. In traditional and classical dramas the conflict had been between metaphysical forces and a human being, but in modern drama especially in O'Neill's drama the conflict exists between human species. In modern time one part of society assumes itself as the possessors of all powers of the world and legitimizes the oppression and tyranny over the other part of the society. One of the critical movements which are constructed in relation to the deplorable situation of the marginal part of the society is Cultural Materialism.

Cultural materialism tries to observe the interaction between State power and cultural forms, and how the theatre has been used as a prime location for the representation of power. For Cultural Materialism the concept of power implies the object of struggle. Cultural materialists define the alien and unruly individuals as 'Other'. The existence of 'Other' is allowed only as evidence of the rightness of established power. Critics like Dollimore and Sinfield argue that the resistance or subversion may indeed be appropriated by authority for its own purpose, but it can be used against authority as well as used by it. Thus, the demonized elements in modernist culture, the subordinate, the marginalized and the dissidents are identified as the forces to be self-identified. In Cultural Materialism the process of resistance is the outcome of the struggle between marginality and power.

The social, political, cultural and economical aspects of O'Neill's contemporary society had affected highly his plays. Some critics categorized his entire plays that all of them at least contain dual aspects: first those peculiar features which are limited to American life and thought, and second those feature that are not limited by either time or place and are rooted in the universal experiences of mankind. In the selected plays studied in the thesis all of those features are illustrated, but Cultural Materialists in their critical investigations are more concerned with the first type features. The Iceman Cometh contains two marginal and influential characters, Parritt's mother and Hickey's wife. Both determine the whole action of the play. In short, the central characters of O'Neill's plays are the really social marginal characters neglected by that world. They have to leave their social and political activities. O'Neill by his characterization implies the importance of the marginal individuals in his society.

\section{The concept of The Iceman Cometh}

The Iceman Cometh represents the inattentiveness and indifference of the modern people. The latter is certainly more harmful for humanity than the former problem. Cultural Materialists argue that the problem of modern man is not consciousness-raising or recognition of the tyrannical procedures of dominant material system; rather it is his indifference to his retrogression and the lack of tendency to save correctly himself from the humanistic falling. The modern man like all Hope's dwellers willingly deceives himself and submits himself to Pipe dreaming, alcohol, coming of the savior and tomorrow work in order to reduce his relief.. O'Neill knows this catastrophe and tries to make it obvious for all people.

The time of The Iceman Cometh is retrospective, the story happened in 1912. The time of two of O'Neill's plays, Long Day's Journey into Night and The Iceman Cometh, is 1912. This year is very disappointing time for O'Neill himself. Within the span of O'Neill's life and literary career, the year 1912 has deep significance. In Cultural Materialistic terminology this year is considered as the historicity of text which influences and constructs the production of the text. In 1912 O'Neill decides to be a playwright. It is in the fall of that year that O'Neill attempts suicide and very soon after its recuperation he is afflicted with tuberculosis that captivates not only O'Neill himself but also his father, his mother and his elder brother Jamie. This experience affects his entire personal and dramatic world. It constructs the world with its often intolerably severe tension and its violent mixture of love, hatred, guilt and resentment that would be the obsessive subject of almost every important play that O'Neill thereafter writes.

One of the other crucial terms of Cultural Materialism that plays a significant role in O'Neill's plays is the concept of power. Cultural Materialists define power in Marxist terms. They under the influence of Michael Foucault argue that all man's social and intellectual activities are the will to power. As soon as the power is established the process of decentring takes place in order to sustain the control and absolute authority. By decentring some part of the society is taken to the marginality. Little by little this marginal part of the society becomes the great threat for the dominant power of the society. Thus, marginal division conflicts with the central power and the struggle between them constructs resistance. The ultimate aim of resistance is to subvert the dominant order. The subversion stands against the attempts of authority in consolidation of its rules. The examination of the concept of the resistance and subversion is the main concern of Cultural 
Materialism. This approach at first recognizes the power or ruling class and then investigates the marginal and dissident class.

The Iceman Cometh is considered as O'Neill's masterpiece which represents the disillusionment of the modern man within the capitalistic society. This play shows O'Neill's worldview and his attitude about the failure of any social reform or hopeful improvement in the time between the World Wars. He depicts a small community of derelicts in Harry Hope's Saloon as a microcosm of the World. The characters in order to make life tolerable escape from reality and deceive themselves by fostering the Pipe dream.

The Iceman Cometh beyond its philosophical or psychological themes, such as facing reality or self deception in various situations, wants to reproach the false dream of America. Virginia Floyd states, "The promise of the American Dream, a goal of material prosperity and success, has long been regarded as a crucial element of American culture" (263). With O'Neill's characters it is capitalism and anarchism that have reached their exhausted end. Floyd also declares, "Neither ism is able to provide its followers with sufficient hope for the present; as a consequence, they retreat into a world of pipe dreams" (268). In Harry Hope's saloon there is no trace of such hope for future glorified days, and just pretension of the coming hopeful days is the only reason for surviving in American life.

O'Neill intentionally refers to his contemporary social and political matters in order to reveal the harsh background which influenced the formation of such downtrodden characters. In representing the quarrel between General Wetjones, one-time leader of a Boer commando, and Captain Lewis, one-time Captain of British infantry in the Boer war, O'Neill tries to show to some extent the policy of imperialistic countries affects the impartial relationship between the people. The characteristic of Joe Mott, the only Negro of the play, is very considerable. It seems that the need of remaining in the Hope's gang forces Mott to accept the dominant's superficial propaganda that there is no difference between the blacks and the whites: "I don't stand for nigger from nobody. In the old days, people call me nigger" (642). This false dream that in materialistic and capitalistic society of America there is no discrimination between black and white is essential for Mott in order to pass his time happily. He by accepting this dream wants to forget the harsh reality. Of course, in some passages that Mott honestly remembers his past, he points to the real racial discrimination of the society for example, in Act one he speaks about the legal permission for opening his gambling House: "I went to see de Chief,...he shouts, You black son of a bitch, Harry says you're white and you better be white or dere's a little iron room up de river waiting for you!" (643). Manheim says: "Being equal with the whites is Mott's pipe dream so that if he wants to be comfortable he inevitably should attach to it" (198). After Hickey preaching about killing all the pipe dreams we see that Mott faces the reality and becomes aware of his false hope "Don't you get in your head I'm pretending to be what I ain't, or that I ain't proud to be what I is, get me? You white boys! You and me's going to have trouble!" (676).

Another important point of The Iceman Cometh is the playwright's idea about the political movement or Anarchism which has a determining role in this play. The clarification of the author's attitude towards the socio-economical and political aspects of his context is very essential in interpreting of the text. Only under such clarification finding out the positions of dissident and dominant, central and marginal, determination and subordination would be possible. O'Neill directly introduces his two anarchist character "Larry Slade, one-time Syndicalist-Anarchist" (Act I 615) and "Hugo Kalaman, one-time editor of Anarchist periodicals" (615), but he indirectly and very effectively depicts Parritt's mother as a chief anarchist in the play. Although she never comes to the stage, her great influence on the process of the story is obvious. During the 1900s anarchy, the belief that all systems of government had been immoral and unnecessary was a serious political movement in the United States. Bogard stresses that "Emma Goldman perhaps the best remembered of the anarchists of this period may have served as a model for Parritt's mother; Goldman was quite active in 1912, the year in which The Iceman Cometh is set" (344). Also in another chapter he pointes to the acquaintance of O'Neill with some anarchists in 1915: "in the Greenwich village after O'Neill had left Harvard, he met Maxwell Bodenheim, Mary Heaton Vorse and the loquacious anarchist, Terry Carlin, whom he later portrayed as Larry Slade in The Iceman Cometh" (398).

O'Neill in act one through a conversation between Joe and Larry informs the audiences about the essence of the Socialist and Anarchist in 1910s from the common people's viewpoint. Joe remembers his last night conversation with his friend about Socialists and Anarchists. His friend says: "we ought to shoot dem dead" (Act I 629), but Joe replies "you talk's if Anarchists and Socialists were the same...No, dey ain't, I'll explain the difference" (629). Then he starts to evaluate the former group's position from his profiteering outlook "De Anarchist he never works...if he do ever get a nickel, he blows it in on bombs, and he wouldn't give you nothing. So go ahead and shoot him" (629). The latter group is better for Joe because he considers them as profit-sharing: "But the Socialist, sometimes, he's got a job, and if he gets tem bucks, he's bound by his religion to split fifty-fifty wid you. And you get de five. So you don't shoot no Socialist" (629). O'Neill by representing this conversation implies that for common people, economical forces determine the value of each political Movement, as we see that Larry justifies his quit the movement: "I saw men... never pay that price for liberty" (624). 
Larry's ideas about the essence, the definition and the deficiency of the revolutionary movement could be O'Neill's idea about such dissidence. The more O'Neill's experiences are increased, the more realist becomes he. He challenges the idealistic promises of dissidents in resistance against the dominant structured system, and identifies their weak points. Larry as the most intellectual member of Hope's saloon through the conflict with Parritt firmly rejects to return to his past Anarchist beliefs in Act One and says, "I am through long since with any connection with them [the sanarchists]. I know they're damned fools, most of them, as stupidly greedy for Power as the worst Capitalists they attack" (632). In another place he considers the Movement as "only beautiful pipe dream" (633) which deceives the people that it certainly would improve their social conditions. Also he condemns the anarchist's ineffective way of resistance and says: "I couldn't go on believing forever that gang was going to change the world by shooting off their loud traps on soapboxes and sneaking around blowing up a lousy building or a bridge! I got wise all a crazy pipe dream!"( 635).

Larry's quit of the dissident movement in Act One doesn't mean that he supports the dominant system. He contends that the anarchist movement is not his satisfactory counteract, and since he doesn't find another effective action he prefers to go outside the system "If I don't believe in the Movement, I don't believe in anything else either, especially not the State. I've refused to become a useful member of its society. I've been a philosophical drunken bum and proud of it" (634). At the same time he proposes his reasons for his decision to leave his companions: "you asked me why I quit the Movement. I had a lot of good reasons. One was myself, and the other was my comrades, and the last was the breed of swine called men in general" (634). After thirty years devotion to the Movement he realizes that he is not made for it: "as history proves, to be a worldly success at anything, especially Revolution, you have to wean blinders like a horse and see only straight in front of you. You have to see that this is all black, and that is all white" (634). Moreover, he accuses all people of his society that they are not ready to convert or to unite with each other to overthrow the capitalistic tyranny. If they don't want to change their oppressive situations, no revolutionary movement can help them: "the free society must be constructed from its men themselves and you can't build a marble temple out of a mixture of mud and manure" (634).

Don Parritt as a victim of his mother's anarchist activities is one of the important characters of the play. He has unpleasant personality: "shifting defiance and ingratiation in his eyes, and irritating aggressiveness in his manner" (625). Throughout the play he wants to instigate Larry to save him from his guilty feeling. He in his confession about his motivation for betrayal mentions different reasons that indicate his unstable mind. One of his confessions which relate to his patriotism reveals the playwright's attention to his contemporary political situations. Parritt in ironical utterances says:

I began studying American history. I got admiring Washington and Jefferson and Jackson and Lincoln. I began to feel patriotic and love this country. I saw it was the best government in the world, where every body was equal and had a chance. I saw that all the ideas behind the Movement came from a lot of Russians like Bakunin and Kropotkin and were meant for Europe, but we didn't need them here in a democracy where we were free already. (686)

Such faithful speeches from a person like Parritt seem somehow strange and unbelievable. Only after two acts, he begins to describe his real motivation, which is his hate toward his mother; thus, his previous lie about the devotion to the democratic American government is revealed. Certainly the arrangement of such paradoxical expressions is not accidental and O'Neill indirectly admits the reverse of Parritt's statements. Most of the characters in The Iceman Cometh are typical. The word 'Type' occurs frequently in the descriptive stage directions of Hope's roomers: Hugo Kalmer bears "a strong resemblance to the Type of Anarchist as portrayed... in newspaper cartoons" (620); Joe Mott's face is "midly negroid in Type" (620); Piet Wetjones is a "Dutch farmer Type" (621). Where the word 'type' indirectly is not mentioned, the idea remains exactly the same; for instance, James Cameron has "a quality about him of a prime, Victorian old maid" (621), Cecil Lewis "is as obviously English as Yorkshire pudding and just as obviously the former army officer" (621), McGloin has "the occupation of policeman stamped all over him" (621) and Ed Mosher "looks like an enlarged, elderly, bald edition of the village fat boy" (621). The typicality of Rocky is stressed as a "Neapolitan-American" (622) and Chuck Morello's as an "Italian-American" (622), while the three women are called "typical dollar streetwalkers" (652). In this play just Larry Slade, Don Parritt and Theodore Hickman are individuals. These three individuals despite the differences are very similar to each other.

Only the individuals of the play are capable of rebellion against their status quo: Larry after thirty years devotion to anarchist movement rebels against it, Parritt rebels against his anarchist mother and betrays her, and Hickey rebels against Hope's gang who trust him and consider him as a savior. He like a revolutionist constructs the inner movement and conversion within Hope's saloon, and disturbs the accustomed atmosphere of it. Brenda Murphy in her article, The Iceman Cometh in Context, believes that "there are different realms of resistance for these three individuals" (18). She assumes Larry is a "political reformist" (19), Parritt is a "moral betrayer" (19) and Hickey is a "psychological and social rebel" (19). She states that "Harry Hope's saloon stands as a microcosm of the world and pipe dream is the accepted 
rule of its inhabitants" (7). The final unchanged situation of the saloon leads us to this reality that in modern capitalistic world there is no hope of improvement for human being. The pipe dreamers have come to Hope's rooming house because they are failures in the outside world. What lies outside is a world without value, full of crises and a hostile society to which no man can possibly belong. In Act Three, Hickey mocks Hope when he hesitates to go out, and says: "you can't hang around all day looking as if you were scared the street outside would bit you!" (719). The threatening automobiles in the street which arouse menace in Hope when he wants to go out symbolize the mechanized, modern and spiritless world.

For the dreamers fostering illusion is the sign of membership in the club and the subject of the pipe dream is not important. Between the characters rule certain principles of mutual acceptance, understanding and tolerance. Elizabeth Nugent mentions:

Each person is aware that the others are pipe dreamers, but he accepts, understands and tolerates all as long as he and his pipe dream too is accepted, understood and tolerated in return. Belonging to Hope's saloon is the main concern of the dreamers. (45)

Hickey and Parritt are considered as the outsiders who fit to no group. They are doomed to affliction: Hickey is sent to electric chair and Parritt commits suicide.

O'Neill reveals the fallacious face of the Capitalist society when in the Third Act Hickey speaks about his past job as a salesman. Hickey confesses that his job is like a game: "sizing people up quickly, spotting what their pet pipe dreams were, and then... pretending you believed what they wanted to believe about themselves. Then they liked you, and trusted you, and wanted to buy something to show their gratitude" (743). Consequently the foundation of economical exchange in such society is based upon deception. According to Dollimore sometimes dissidence is embedded in the dominant system or is fed back by it; so, we realize that the whole socio-economical procedures in O'Neill's society focus on both self and other deception. Dollimore mentions "dissident is not always in conflict with the dominant, rather there may be supportive relation between them that without one of them the other could not survive" (qtd in Brannigan 95).

O'Neill by representing such circumstances in The Iceman Cometh deliberately intends to convey that in all epochs of the history there are some individuals who under the influence of certain forces become nonconformists and attempt to oppose the common socio-political currents of their society. By denying the prevalent forces of the governing system, they inevitably have to leave the system, like Hope's gang. Kenneth Tynan in The Review of The Iceman Cometh indicates, "O'Neill is one of the few writers who can enter, without condescension or contempt, the world of those whom the world has neglected" (qtd in Floyd 70). All characters of the play had been the active members of their society before, but as soon as they protest against the dominant structure they were obliged to be passive. They come to the end of their usefulness as Larry describes the position of the saloon: "It's no chance saloon, the end of the line, the bottom of the sea... the last harbor. No one here has to worry about where they're going next, because there is no farther they can go" (631). In such condition facing reality and thinking about the value of their fighting bring nothing for them, except the uncomfortable and irritating mood. Thus, they take refuge in the pipe dreams in order to continue their life as Larry states: "here they keep up the appearance of the life with a few harmless pipe dreams about their yesterdays and tomorrows" (631). Pipe dream is the only cause of their life, and O'Neill at the end of the play leaves Larry to decide whether to join the community with the peace of illusion or to face the stark reality of life.

\section{Conclusion}

O'Neill confessed that the United States instead of being the most successful country in the world is the greatest failure because of the foreign policy of the United States during the Wars. The Iceman Cometh is the symbolic and artistic picture of the US policy which brings disillusionment and death for Americans.O'Neill held out little hope for man in The Iceman Cometh during the Second World War. O'Neill confessed that the United States instead of being the most successful country in the world is the greatest failure because of the foreign policy of the United States during the Wars. The Iceman Cometh is the symbolic and artistic picture of the US policy which brings disillusionment and death for Americans. In the post war context of The Iceman Cometh there are different types of dissidents who try to rebel against their hopeless life, but they prefer to dream in order to forget their misery. This paper firstly deals with the dissidents in the play and secondly with their motivations for their resistance. Thus, some specific elements of Cultural Materialism are intended in this paper such as the concept of power, the representation of the resistance and the struggle between the marginal and central groups of society. 


\section{References}

Abrams, M. H. 1993. A Glossary of Literary Terms. New York: Harcourt Brace Pub.

Barker, Chris. Cultural Studies: Theory and Practice. London: Sage publication Inc, 2004.

Bayem, Nina, ed. 1994. The Norton Anthology of American Literature. 4th ed. New York: Norton press.

Bogard, Travis. 1972. Contour in Time: The Plays of Eugene O'Neill. New York: Oxford UP.

Dusenbury, Winifred. 1960. The Theme of Loneliness in Modern American Drama. New York: Gainesvildge Pub.

Dollimore, J. and Sinfield, A. Political Shakespeare: Essays in Cultural Materialism. London: Manchester University Press, 1994.

Floyd, Virginia. 1981. Eugene O'Neill at Work. New York: Ungar Pub.

Gessner, John.ed. 1946. Eugene O’Neill: A Collection of Critical Essays. New York: Englewood Cliffs.

Krasner, David.ed. 2005. A Companion to Twentieth Century American Drama. New York: Blackwell Pub.

Krutch, Joseph Wood. 1957. American Drama Since 1918. New York: Addison-Wesely Publishing Company.

Lodge, David, ed. 2000. Modern Criticism and Theory. New York: Longman Pub.

Manheim, Micheal.ed. 1998. The Cambridge Companion to Eugene O'Neill. New York: Cambridge UP.

Nugent, Elizabeth. 1965.The Iceman Cometh: A Critique. New York: Monarch Press.

Rodgers, David. 1965. The Plays of Eugene O'Neill: A Critical Commentary. New York: Monarch Press.

Summers, Martin. 1900-1930. Manliness and its Discontents: The Black Middle Class and the Transformation of Masculinity, New York: North Caroline UP.

Abdo, Diya. The Emperor Jones: A Struggle for Individuality. Wilkins, Fredrick.ed.

The Eugene O'Neill Review: volume 24, No I\& II. Spring-Fall 2000.1/5/2004. <http://www. eOneill.com/review/htm>.

Murphy, Brenda. The Iceman Cometh in Context: An American Saloon Trilogy.

Brietzke, Zander.ed. The Eugene O'Neill Newslette. Volume V, No II.

Summer-Fall 1981. 6/16/2004. <http:// www. eOneill.com/Newsletter/htm>. 